This is the final peer-reviewed accepted manuscript of:

Selective Oxidation of Amines to Aldehydes or Imines using Laccase-Mediated BioOxidation, ADVANCED SYNTHESIS \& CATALYSIS - ISSN:1615-4150 2015, vol. 357 (8), pp.1840-1848

Paola, Galletti; Federica, Funiciello; Roberto, Soldati; Daria, Giacomini

The final published version is available online at: DOI:10.1002/adsc.201500165

Rights / License:

The terms and conditions for the reuse of this version of the manuscript are specified in the publishing policy. For all terms of use and more information see the publisher's website.

This item was downloaded from IRIS Università di Bologna (https://cris.unibo.it/)

When citing, please refer to the published version. 


\title{
Selective O xidation of Amines to Aldehydes or Imines using Laccase-Mediated Bio-Oxidation
}

\author{
Paola Galletti, ${ }^{\mathrm{a}, *}$ Federica Funiciello, ${ }^{\mathrm{a}}$ Roberto Soldati, ${ }^{\mathrm{a}}$ and Daria Giacomini ${ }^{\mathrm{a}, *}$ \\ ${ }^{\text {a }}$ Department of Chemistry “G. Ciamician”, University of Bologna, 40126 Bologna, Italy
}

\begin{abstract}
An efficient and practical chemo-enzymatic aerobic oxidation in water of benzylamines to obtain aldehydes or imines is described. Laccase from Trametes versicolor was chosen as biocatalyst, and TEMPO (radical 2,2,6,6-tetramethylpiperidine 1oxyl) as mediator. A study on the $\mathrm{pH}$ dependence of the aqueous medium allowed us to realise a fine
\end{abstract}

tuning on product selectivity. Under our optimized reaction conditions, the bio-oxidation of a series of primary, secondary and cyclic amines has been achieved.

Keywords : aldehydes; amines; enzyme catalysis; imines; oxidation

\section{Introduction}

Selective oxidation of amines is an important tool to get functional group interconversions in organic synthesis. Depending on the amine, catalytic system, reaction conditions, and oxidizing agent, a panel of different products could be obtained, such as, for instance, carbonyl compounds, amides, nitriles, and so on (Figure 1).[1] Great progress has been made in recent years in developing catalytic and selective

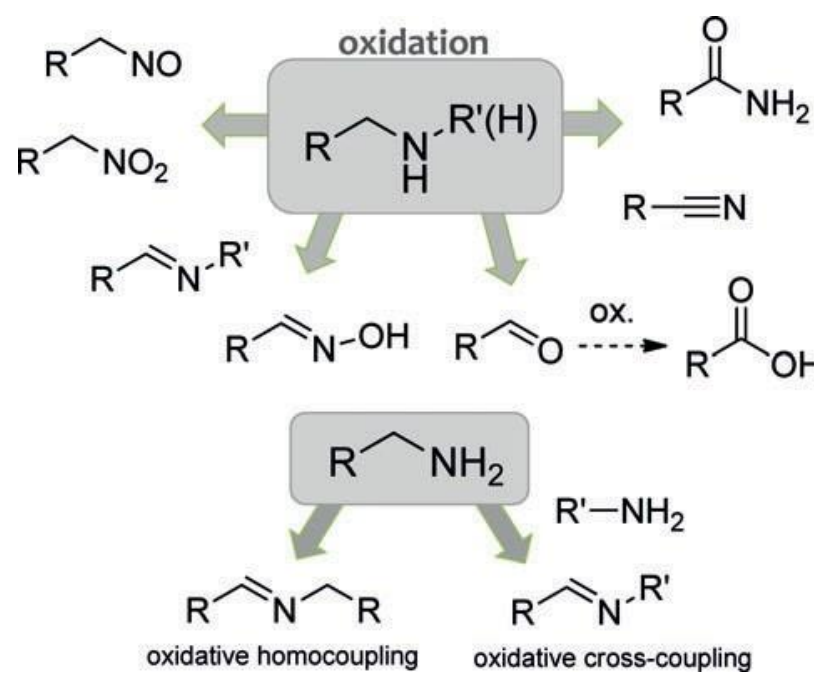

Figure 1. Functional group diversity generated by amine oxidation. methods for amine oxidation.[2] Focusing on primary amines, some relevant transformations should be considered: the oxidation to nitriles or carbonyl compounds, the oxidative self-condensation of the starting substrates to give imines, and with a second amine, the oxidative cross-coupling to give cross imines (Figure 1).

The oxidative dehydrogenation of amines has often been based on transition metal complexes, as catalysts, under aerobic conditions with molecular oxygen as final oxidant ${ }^{[3]}$ and in water as solvent. ${ }^{[4]}$ Other approaches utilized $\mathrm{Cu}$ salts/ $N$-oxyl radical systems, ${ }^{[5,6]}$ metal-organic framework solids, ${ }^{[7]}$ gold catalysis, ${ }^{[8]}$ metal-free aerobic conditions ${ }^{[9]}$ and, very recently, $\mathrm{TiO}_{2}$ photocatalytic oxidation in water.[10] However, many of these systems still require harsh reaction conditions, give metal-containing wastes, and selectivity can be difficult to achieve and control.

Biocatalysis is emerging as a valuable tool to develop more benign and selective redox processes. ${ }^{[11]}$ Biooxidations could have higher selectivity (regio-, chemo-, or stereo-) suitable even for fine chemicals with complex structures and oxidation-sensitive functional groups.[12] In nature, copper amine oxidases (CAOs, EC 1.4.3.21 and EC 1.4.3.22) couple the oxidation of primary amines to aldehydes with the reduction of molecular oxygen to hydrogen peroxide using ortho-quinone cofactors. ${ }^{[13]}$ By mimicking CAOs, biomimetic aerobic oxidation of primary benzylamines has been recently achieved by using quinones as catalysts. ${ }^{[14]}$ 
Laccases belong to the multi-copper family of oxidases (EC 1.10.3.2); they contain four copper centres per protein molecule and catalyse the oxidation of electron-rich aromatic substrates, usually phenols or aromatic amines using oxygen as the electron acceptor. ${ }^{[15]}$ Water being the only by-product, laccases are ideal catalysts for sustainable chemical and technological processes. In fact, they can be used in organic synthesis, have industrial applications, and offer great applications in environmental biotechnology. ${ }^{[16]}$

Although the natural substrates of laccases are phenolic residues of lignin, the use of mediators in the laccase-mediator system (LMS) makes accessible the oxidation of non-phenolic substrates.[17]

Application of LMS in the bio-oxidation of alcohols is well documented in the literature. ${ }^{[18]}$ Recently, we reported an application of LMS in the oxidation of some primary alcohols to the corresponding aldehydes and carboxylic acids. Moreover, we succeeded in a relevant application, developing the LMS-oxidation of 2-arylpropanols (profenols) to the corresponding 2-arylpropionic acids (profens), in high yields and with a complete retention of configuration. ${ }^{[19]}$ Concerning the oxidation of amines only few applications of laccases were reported, mainly on anilines. ${ }^{[20]}$

Herein we describe a selective oxidation of amines employing laccase from Trametes versicolor (Laccase $\mathrm{Tv})$ as the enzyme, TEMPO (2,2,6,6-tetramethylpiperidine 1-oxyl radical) as mediator and $\mathrm{O}_{2}$ as oxidant, in buffered water as solvent. We found that, depending on the reaction conditions, the bio-oxidation could be selectively driven to give the corresponding aldehydes or imines in good yields.

\section{Results and Discussion}

The bio-oxidation of amines was initially investigated starting from the reaction conditions optimized for alcohol oxidation, as we previously reported:[19] Laccase Tv (Sigma-Aldrich, $5 \mathrm{mg}, 50$ units), 2,2,6,6-tetramethylpiperidine 1-oxyl (TEMPO; free radical) $20 \mathrm{~mol} \%$ in water $(6 \mathrm{~mL})$ at room temperature with $\mathrm{O}_{2}$ bubbled into the reaction vessel for $30 \mathrm{sec}$. In a preliminary attempt para-methoxybenzylamine $(1 \mathrm{a}, 0.5 \mathrm{mmol})$, chosen as a model substrate, did not react (Table 1 , entry 1). The use of unbuffered water as reaction medium, which gave good results with alcohols, ${ }^{[19]}$ in this case failed maybe due to inactivation of Laccase $\mathrm{Tv}$ at the basic $\mathrm{pH}$ generated by amine dissolution in $\mathrm{H}_{2} \mathrm{O}$. ${ }^{21]}$ The use of acetate buffer at $\mathrm{pH} 4.5$ then resulted in a successful reaction and 1a was quantitatively converted in the corresponding aldehyde $2 \mathrm{a}$ in $24 \mathrm{~h}$ (Table 1 , entry 2 ). The product $2 \mathrm{a}$ was easily isolated in quantitative yields from the reaction mixture by a simple solvent extraction (see Experimental Section). We extended the reaction time to 7 days to test the possibility of a further oxidation of the aldehyde to the corresponding para-methoxybenzoic acid (3a), ${ }^{[19]}$ but only the aldehyde was recovered (Table 1 , entry 3). Use of a lower amount of the enzyme was evaluated and it was observed that the efficiency of the bio-oxidation was maintained until $0.1 \mathrm{mg}(1 \mathrm{U})$ of Laccase Tv, (Table 1, entry 6), even if after $24 \mathrm{~h}$ the reaction was not complete (conversion 83\%) and a considerable amount of the imine $4 \mathrm{a}$ was isolated after work-up (Table 1, entry 6). On extending the reaction time to 7 days aldehyde 2 a was quantitatively recovered (Table 1, entry 7). Our attention was then focused on the aqueous reaction medium, and we observed that on lowering the concentration of acetate buffer from $0.5 \mathrm{M}$ to $0.2 \mathrm{M}$, a complete conversion was reached in a shorter reaction time (Table 1, entry 8 versus 2). To stoichiometrically buffer the amine basicity and use the lowest amount of acetate, unbuffered $\mathrm{H}_{2} \mathrm{O}$ with 1 equiv. of acetic acid as additive was tested on $1 \mathrm{a}$, and an efficient oxidation to aldehyde 2 a was achieved (Table 1, entry 9). Under these conditions amine and acetic acid formed the corresponding ammonium salt and the amount of free amine in the aqueous solution depends on the hydrolysis constant of the salt. On consuming the free amine by oxidation, the $\mathrm{pH}$ of the reaction solution is lowered by the increasing release of acetic acid from the salt hydrolysis. At neutral $\mathrm{pH}$, phosphate buffer $\mathrm{pH} 7$, conversions of $50 \%$ and $83 \%$ were reached in 24 and $48 \mathrm{~h}$, respectively. It is interesting to note that at this $\mathrm{pH}$ a complete selectivity towards the imine $4 \mathrm{a}$ was obtained after work-up (Table 1, entries 10-12).

TEMPO, the redox mediator in the oxidation with laccase, is needed in sub-stoichiometric amounts because laccases constantly restore the oxamonium ion responsible for the oxidation of the substrate. ${ }^{[22]}$ We then tested the reaction on lowering the amount of TEMPO: from 20 to $10 \mathrm{~mol} \%$ at $\mathrm{pH} 4.5$ the reaction proceeded well with complete conversion and total product selectivity towards the aldehyde, whereas using 5 and $2.5 \mathrm{~mol} \%$ lower conversion and selectivity were obtained (Table 1, entries 13, 14 and 17). On lowering the TEMPO mol\% at $\mathrm{pH} 7$, the reaction was slowed down and the conversion was poor but after the work-up only the imine 4 a was recovered (Table 1, entries 15, and 16). On extending the reaction time to 4 days with TEMPO $2.5 \mathrm{~mol} \%$, the conversion was complete and the imine $4 \mathrm{a}$ was isolated in $95 \%$ yields (Table 1, entry 18 ).

Under standard conditions benzylamine $1 \mathrm{~b}$ in $24 \mathrm{~h}$ (TEMPO $20 \mathrm{~mol} \%$ and acetate buffer, Table 1 , entry 19) gave quantitatively benzaldehyde $2 b$, on extending the reaction time to 10 days, as well as on lowering the buffer concentration to $0.2 \mathrm{M}$, considerable amounts of benzoic acid were detected in the reaction mixture (Table 1, entries 20 and 21). 
Table 1. Optimization of reaction conditions.[a]

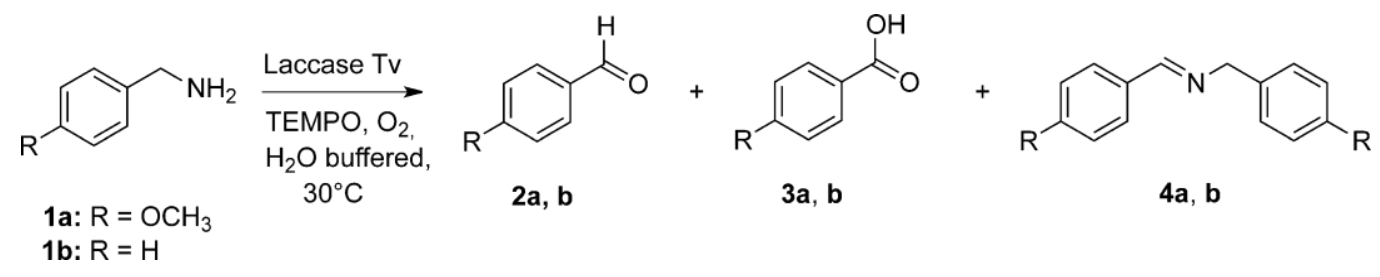

\begin{tabular}{|c|c|c|c|c|c|c|c|c|}
\hline Entry & Substrate & Buffer, $\mathrm{pH}$, conc. & $\begin{array}{l}\text { Enzyme } \\
{[\mathrm{mg}]}\end{array}$ & $\begin{array}{l}\text { TEMPO } \\
{[\mathrm{mol} \%]}\end{array}$ & Time $^{[b]}$ & $\begin{array}{l}\text { Conversion } \\
{[\%]^{[c]}}\end{array}$ & $\begin{array}{l}\text { Selectivity } \\
2 / 3 / 4^{[\mathrm{d}]}\end{array}$ & $\begin{array}{l}\text { Product } \\
\text { (Yield [\%])[e] }\end{array}$ \\
\hline 1 & $1 \mathrm{a}$ & unbuffered water, r.t. & 5 & 20 & $8 \mathrm{~d}$ & 0 & - & - \\
\hline 2 & $1 \mathrm{a}$ & acetate, $\mathrm{pH} 4.5,0.5 \mathrm{M}$ & 5 & 20 & $24 \mathrm{~h}$ & $>99$ & $100 / 0 / 0$ & $2 \mathrm{a}(>99)$ \\
\hline 3 & $1 \mathrm{a}$ & acetate, $\mathrm{pH} 4.5,0.5 \mathrm{M}$ & 5 & 20 & $7 \mathrm{~d}$ & $>99$ & $100 / 0 / 0$ & $2 \mathrm{a}(>99)$ \\
\hline 4 & $1 \mathrm{a}$ & acetate, $\mathrm{pH} 4.5,0.5 \mathrm{M}$ & 2.5 & 20 & $24 \mathrm{~h}$ & $>99$ & $100 / 0 / 0$ & $2 \mathrm{a}(>99)$ \\
\hline 5 & $1 \mathrm{a}$ & acetate, $\mathrm{pH} 4.5,0.5 \mathrm{M}$ & 1 & 20 & $24 \mathrm{~h}$ & $>99$ & $100 / 0 / 0$ & $2 \mathrm{a}(>99)$ \\
\hline 6 & $1 \mathrm{a}$ & acetate, $\mathrm{pH} 4.5,0.5 \mathrm{M}$ & 0.1 & 20 & $24 \mathrm{~h}$ & 83 & $60 / 0 / 40$ & - \\
\hline 7 & $1 \mathrm{a}$ & acetate, $\mathrm{pH} 4.5,0.5 \mathrm{M}$ & 0.1 & 20 & $7 \mathrm{~d}$ & $>99$ & $100 / 0 / 0$ & $2 \mathrm{a}(96)$ \\
\hline 8 & $1 \mathrm{a}$ & acetate, $\mathrm{pH} 4.5,0.2 \mathrm{M}$ & 5 & 20 & $3.5 \mathrm{~h}$ & $>99$ & $100 / 0 / 0$ & $2 a(95)$ \\
\hline 9 & $1 \mathrm{a}$ & 1 equiv. acetic acid & 5 & 20 & $2.5 \mathrm{~h}$ & $>99$ & $100 / 0 / 0$ & $2 a(>99)$ \\
\hline 10 & $1 \mathrm{a}$ & phosphate, $\mathrm{pH} 7,0.5 \mathrm{M}$ & 5 & 20 & $24 \mathrm{~h}$ & 50 & $0 / 0 / 100$ & $4 a(32)$ \\
\hline 11 & $1 \mathrm{a}$ & phosphate, $\mathrm{pH} 7,0.5 \mathrm{M}$ & 5 & 20 & $48 \mathrm{~h}$ & 83 & $0 / 0 / 100$ & $4 a(80)$ \\
\hline 12 & $1 \mathrm{a}$ & phosphate, $\mathrm{pH} 7,0.5 \mathrm{M}$ & 0.1 & 20 & $24 \mathrm{~h}$ & 15 & $0 / 0 / 100$ & $4 a(8)$ \\
\hline 13 & $1 \mathrm{a}$ & acetate, $\mathrm{pH} 4.5,0.5 \mathrm{M}$ & 5 & 10 & $24 \mathrm{~h}$ & $>99$ & $100 / 0 / 0$ & $2 a(>99)$ \\
\hline 14 & $1 \mathrm{a}$ & acetate, $\mathrm{pH} 4.5,0.5 \mathrm{M}$ & 5 & 5 & $24 \mathrm{~h}$ & 62 & $60 / 0 / 40$ & - \\
\hline 15 & $1 \mathrm{a}$ & phosphate, $\mathrm{pH} 7,0.5 \mathrm{M}$ & 5 & 5 & $24 \mathrm{~h}$ & 45 & $0 / 0 / 100$ & $4 a(24)$ \\
\hline 16 & $1 \mathrm{a}$ & phosphate, pH $7,0.5 \mathrm{M}$ & 5 & 2.5 & $24 \mathrm{~h}$ & 35 & $0 / 0 / 100$ & $4 a(20)$ \\
\hline 17 & $1 \mathrm{a}$ & acetate, $\mathrm{pH} 4.5,0.5 \mathrm{M}$ & 5 & 2.5 & $24 \mathrm{~h}$ & 44 & $80 / 0 / 20$ & - \\
\hline 18 & $1 \mathrm{a}$ & phosphate, $\mathrm{pH} 7,0.5 \mathrm{M}$ & 5 & 2.5 & $4 \mathrm{~d}$ & $>99$ & $0 /<5 / 95$ & $4 a(95)$ \\
\hline 19 & $1 b$ & acetate, $\mathrm{pH} 4.5,0.5 \mathrm{M}$ & 5 & 20 & $24 \mathrm{~h}$ & $>99$ & $100 / 0 / 0$ & $2 b(98)$ \\
\hline 20 & $1 b$ & acetate, $\mathrm{pH} 4.5,0.5 \mathrm{M}$ & 5 & 20 & $10 \mathrm{~d}$ & $>99$ & $57 / 43 / 0$ & - \\
\hline 21 & $1 b$ & acetate, $\mathrm{pH} 4.5,0.2 \mathrm{M}$ & 5 & 20 & $10 \mathrm{~d}$ & $>99$ & $61 / 39 / 0$ & - \\
\hline 22 & $1 b$ & acetate, $\mathrm{pH} 4.5,0.5 \mathrm{M}$ & 5 & 2.5 & $3 \mathrm{~d}$ & 90 & $75 / 0 / 25$ & - \\
\hline 23 & $1 b$ & acetate, $\mathrm{pH} 4.5,0.5 \mathrm{M}, 508 \mathrm{C}$ & 5 & 20 & $10 \mathrm{~d}$ & $>99$ & $100 / 0 / 0$ & $2 b(>99)$ \\
\hline 24 & $1 b$ & phosphate, $\mathrm{pH} 7,0.5 \mathrm{M}$ & 5 & 2.5 & $2 \mathrm{~d}$ & 40 & $0 / 0 / 100$ & $4 \mathrm{~b}(36)$ \\
\hline 25 & $1 b$ & phosphate, $\mathrm{pH} 7,0.5 \mathrm{M}$ & 5 & 2.5 & $4 \mathrm{~d}$ & $>99$ & $0 /<5 / 95$ & $4 b(92)$ \\
\hline 26 & $1 \mathrm{a}$ & acetate, $\mathrm{pH} 4.5,0.5 \mathrm{M}$ & - & 20 & $4 \mathrm{~d}$ & 0 & - & - \\
\hline 27 & $1 \mathrm{a}$ & phosphate, $\mathrm{pH} 7,0.5 \mathrm{M}$ & - & 20 & $7 \mathrm{~d}$ & 0 & - & - \\
\hline
\end{tabular}

${ }^{[a]}$ Reaction conditions: Laccase $\mathrm{Tv}$, substrate $(0.5 \mathrm{mmol})$, aqueous buffer $(6 \mathrm{~mL})$, bubbled $\mathrm{O}_{2}$ in closed vial.

${ }^{[b]}$ Reaction time reported in days (d) or hours (h).

${ }^{[c]}$ Conversion determined on the crude reaction mixture after the work-up.

${ }^{[\mathrm{dd}]}$ Ratio between aldehyde, acid, and imine has been evaluated by ${ }^{1} \mathrm{H}$ NMR (see Experimental Section).

${ }^{[\mathrm{e}]}$ Yields determined on the crude by ${ }^{1} \mathrm{H}$ NMR after solvent extraction and evaporation (see Experimental Section).

To force the formation of the carboxylic acid, the reaction was kept at $508 \mathrm{C}$ for longer times but only the aldehyde was recovered (Table 1, entry 23). At pH 7 and TEMPO 2.5 mol\%, conversion and selectivity towards the imine $4 \mathrm{~b}$ were complete, and only traces of a further oxidation to benzoic acid were observed after 4 days (Table 1, entries 24 and 25). As control experiments the reaction was conducted in the absence of laccase, with TEMPO $20 \mathrm{~mol} \%$ and $\mathrm{O}_{2}$ at pH 4.5 and pH 7 (Table 1, entries 26 and 27), as expected the oxidation did not proceed.

From the initial screening, $\mathrm{pH}$ conditions emerged as a parameter to control kinetic and selectivity of the bio-oxidation.
Therefore, we performed time course experiments for the oxidation of amine $1 \mathrm{a}$ under three different medium conditions : acetate buffer $\mathrm{pH} 4.5,0.5 \mathrm{M}$ and $0.2 \mathrm{M}$, or $\mathrm{H}_{2} \mathrm{O}$ with 1 equivalent of acetic acid as additive (Figure 2). The reaction mixture was analysed via HPLC by sampling until complete conversions.

In acetate buffer $0.5 \mathrm{M}$ the reaction required $24 \mathrm{~h}$ to give the aldehyde $2 \mathrm{a}$, whereas on decreasing the buffer concentration $(0.2 \mathrm{M})$ or in the presence of acetic acid in $\mathrm{H}_{2} \mathrm{O}$ the reaction was faster and complete in 3-4 h. It is indeed likely that a high buffer concentration could be detrimental, to some extent, for TEMPO oxidation or for solubility of reactants in 


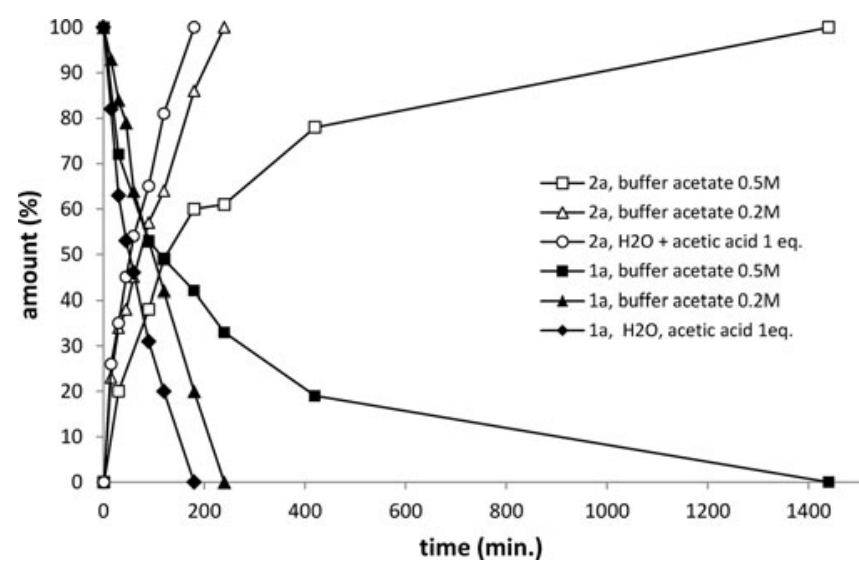

Figure 2. Time course of enzymatic oxidation: amine 1a consumption (filled tag), and aldehyde 2 a formation (empty tag) depending on buffer concentration or additive.

the aqueous medium and that this resulted in a worsening of the whole process.

The bio-oxidation reaction is quite clean and its progress could be easily monitored by ${ }^{1} \mathrm{H}$ NMR spectroscopy: as the amine 1a was consumed the aldehyde
$2 \mathrm{a}$ appeared. Figure 3 reports a time course ${ }^{1} \mathrm{H}$ NMR analysis performed in $\mathrm{D}_{2} \mathrm{O}$ with 1 equivalent of acetic acid as additive. In detail, in an NMR tube, 1a $(0.05 \mathrm{mmol}), \quad \mathrm{D}_{2} \mathrm{O} \quad(0.6 \mathrm{~mL})$ and acetic acid (0.05 mmol) were mixed, then TEMPO (0.01 mmol) and Laccase Tv $(0.5 \mathrm{mg}, 5 \mathrm{U})$ were added and finally $\mathrm{O}_{2}$ was bubbled for 30 seconds, the spectrum was recorded (upper spectrum, Figure 3), and the NMR tube was then stirred on an orbital shaker at $150 \mathrm{rpm}$ at 30 8C. After $60 \mathrm{~min}$ the tube was re-analysed and a second spectrum was obtained (Figure 3). The NMR analysis showed that from the very beginning together with ${ }^{1} \mathrm{H}$ signals of the starting amine $(\mathrm{a}-\mathrm{d})$, traces of the aldehyde $2 \mathrm{a}$ appeared (signals $\mathrm{e}-\mathrm{h}$ ). After 60 min the aldehyde was as expected much more abundant (about 30\%) and noteworthy ${ }^{1} \mathrm{H}$ NMR analysis showed that during the reaction course no other detectable intermediates or by-products were present in the reaction mixture.

With a similar NMR protocol, we analysed the reaction under the conditions to selectively get the imine. Amine 1a, Laccase Tv/TEMPO in buffer phosphate at $\mathrm{pH} 7$ in $\mathrm{D}_{2} \mathrm{O}$ were mixed, then $\mathrm{O}_{2}$ was bubbled for 30 seconds.

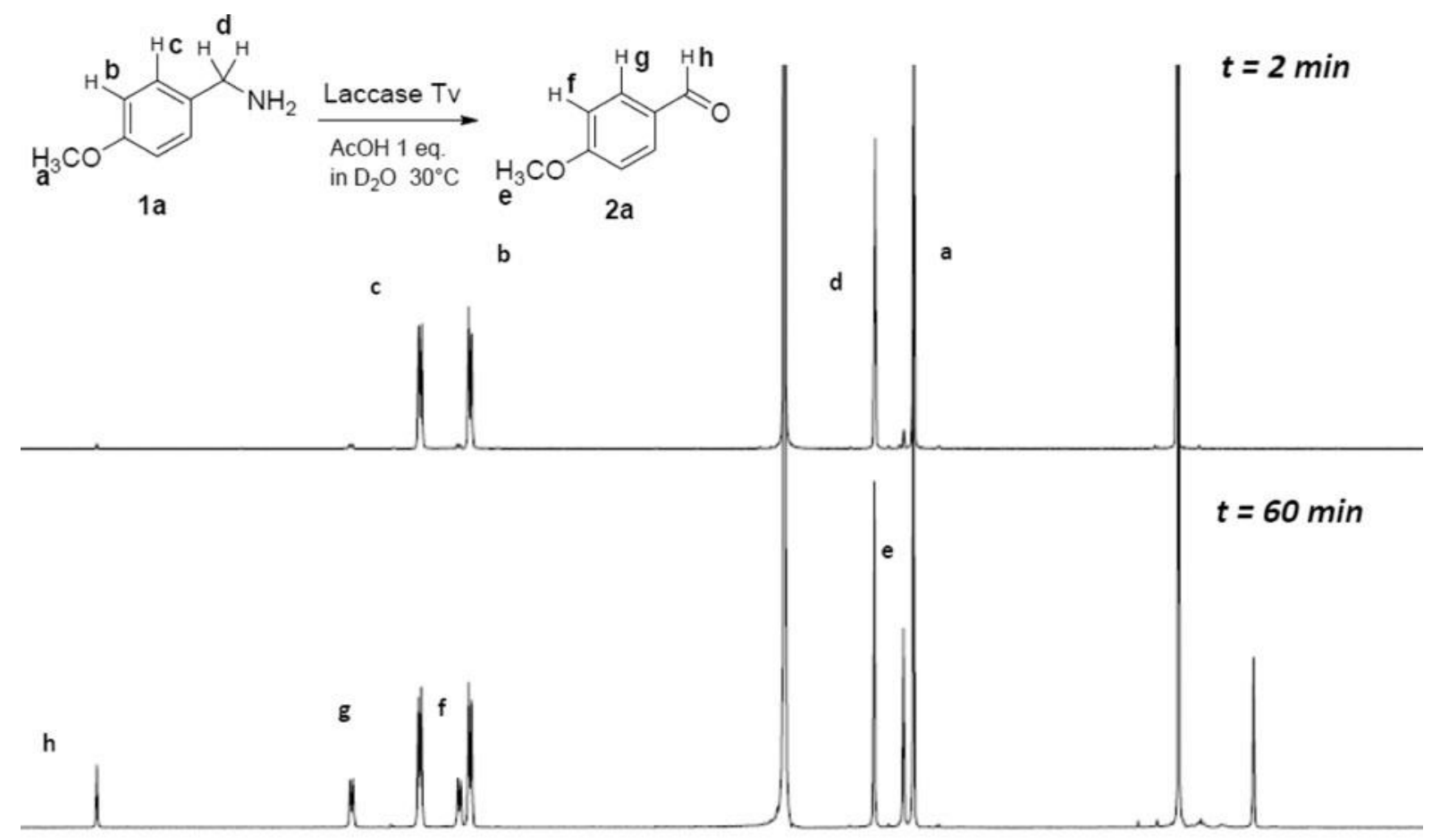

\begin{tabular}{rlllllllllllllllllllll}
\hline 10.0 & 9.5 & 9.0 & 8.5 & 8.0 & 7.5 & 7.0 & 6.5 & 6.0 & 5.5 & 5.0 & 4.5 & 4.0 & 3.5 & 3.0 & 2.5 & 2.0 & 1.5 & 1.0 & 0.5 \\
\end{tabular}

Figure 3. ${ }^{1} \mathrm{H}$ NMR time course analysis for Laccase Tv/TEMPO oxidation of amine 1a into aldehyde $2 \mathrm{a}$ in $\mathrm{D}_{2} \mathrm{O}$ and 1 equiv. of $\mathrm{AcOH}$ as additive. Upper spectrum: reaction mixture at $t=2 \mathrm{~min}$, signals of starting amine $1 \mathrm{a}$ tagged with a, b, c, d; bottom spectrum: reaction mixture at $60 \mathrm{~min}$, signals of aldehyde $2 \mathrm{a}$ appear, tagged as e, $\mathrm{f}, \mathrm{g}$, $\mathrm{h}$. 


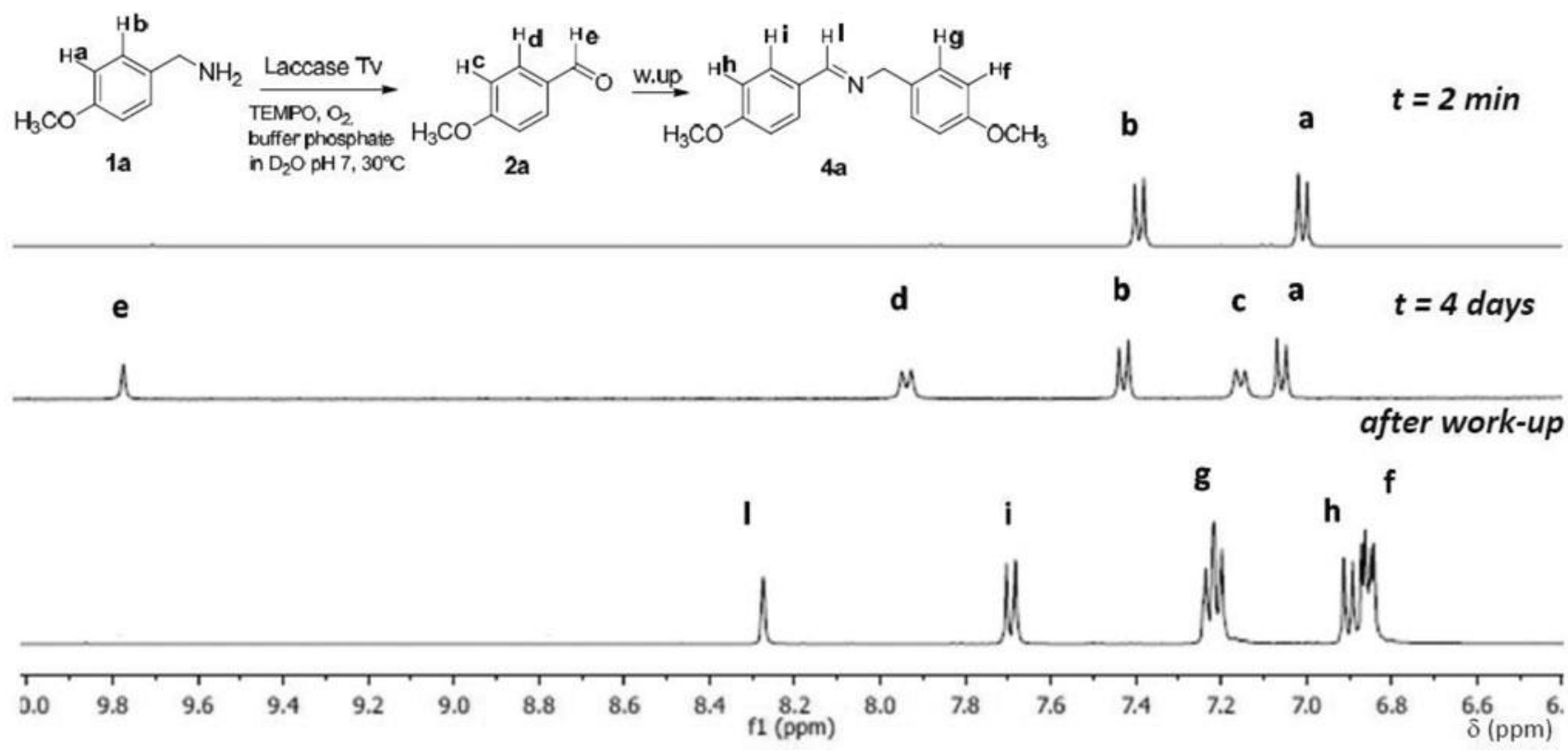

Figure 4. ${ }^{1} \mathrm{H}$ NMR time course analysis for Laccase Tv/TEMPO oxidation of amine $1 \mathrm{a}$ in deuterated phosphate buffer ( $\mathrm{pH} 7$ ) in $\mathrm{D}_{2} \mathrm{O}$ in an NMR tube. Upper spectrum: initial time, signals of starting amine 1a, tagged as a, b; central spectrum: reaction mixture after 4 days, a mixture of amine $1 \mathrm{a}$ and aldehyde $2 \mathrm{a}$ is present (no imine signals), aldehyde signals tagged as c, d, e; bottom spectrum: reaction mixture after work-up, only signals of imine 4 a are present, tagged as f, g, h, i, l.

On direct sampling and NMR analysis of the reaction mixture, after 2 min, only the starting amine $1 \mathrm{a}$ was detected (Figure 4), after 4 days we found a 1:1 mixture of amine $1 \mathrm{a}$ and aldehyde $2 \mathrm{a}$ and no imine present, while after the work-up, imine $4 \mathrm{a}$ was the only product detected (Figure 4). As a control experiment, equimolar amounts of the commercially available aldehyde $2 \mathrm{a}$ and the amine $1 \mathrm{a}$ were mixed in buffer phosphate at $\mathrm{pH} 7$ in $\mathrm{D}_{2} \mathrm{O}$ but in $24 \mathrm{~h}$ no traces of the corresponding imine $4 \mathrm{a}$ were detected. It could be then concluded that the imine is not a reaction intermediate and its quantitative obtainment occurred during work-up (solvent extraction and evaporation) when the starting amine underwent condensation with the aldehyde just formed in the bio-oxidation. It was already reported in the literature that a direct mixing of aldehyde $2 \mathrm{a}$ and amine $1 \mathrm{a}$ without solvent (neat) or in methanol gave the corresponding imine without any catalyst. ${ }^{[23]}$ Having explored the reaction conditions for amines $1 \mathrm{a}$ and $1 \mathrm{~b}$, the optimal conditions to selectively obtain aldehydes $(2 \mathrm{a}, \mathrm{b})$ or imines $(4 \mathrm{a}, \mathrm{b})$ were then established as follows: buffer acetate

$\mathrm{pH} 4.5$ at shorter reaction time for obtaining aldehydes, and eventually carboxylic acids at longer reaction time, buffer phosphate $\mathrm{pH} 7$ for obtaining imines. Concerning the mechanism of the amine oxidation by laccase-TEMPO, a tentative hypothesis could be formulated starting from the ionic route proposed for LMS oxidation of alcohols (Figure 5).[19]

The effectiveness of the process could depend on the facility of hydrogen abstraction on the starting

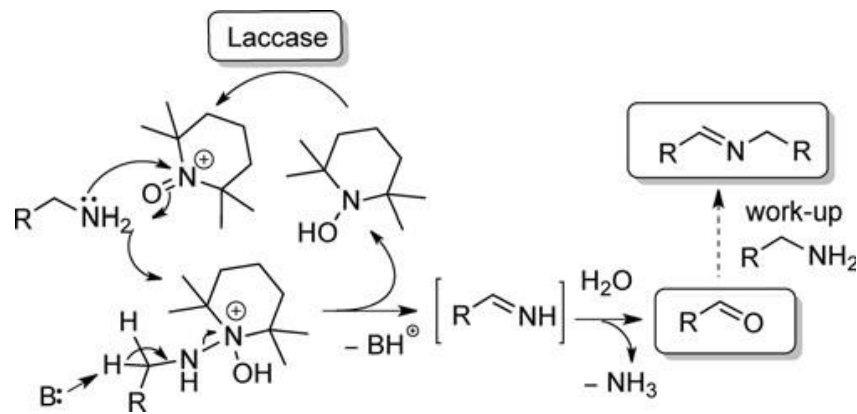

Figure 5. Proposed mechanism for the bio-oxidation of benzylamines by Laccase Tv and TEMPO.

amine supported by observation of an easier oxidation of benzylamines than alkylamines, together with ammonia elimination to give the aldehyde.

If the medium conditions slow down the reaction rate at a $50 \%$ conversion in the work-up procedure condensation of the residual starting amine with the aldehyde gave the imine.

Noteworthy, the aerobic oxidative homo-coupling of amines to imines is going to attract great attention as a valuable alternative to the traditional amine-carbonyl condensation, $, 7 \mathrm{7a}, 24]$ and this is the first result on such an oxidation obtained with enzymatic catalysis.

To study the applicability of the amine bio-oxidation, the scope of the reaction was extended to a series of primary amines (Table 2), under the optimized conditions for a controlled product selectivity. Octylamine (1c), as a model of aliphatic amines, did 
Table 2. Bio-oxidation of primary amines.[a]

\begin{tabular}{|c|c|c|c|c|c|c|c|}
\hline \multirow[b]{2}{*}{ Entry } & \multirow[b]{2}{*}{ Substrate } & $\begin{array}{l}\mathrm{H}_{2} \mathrm{O} \text { buffered, } \\
30^{\circ} \mathrm{C}\end{array}$ & \multirow{2}{*}{$\begin{array}{l}\text { c-I } \\
\text { TEMPO } \\
{[\%]}\end{array}$} & \multirow{2}{*}{$\frac{4 c-I}{\text { Time }^{[b]}}$} & \multirow{2}{*}{\multicolumn{2}{|c|}{$\begin{array}{l}\text { Conv. Selectivity } \\
{[\%]^{[c]} 2 / 3 / 4^{[\mathrm{d}]}}\end{array}$}} & \multirow[b]{2}{*}{$\begin{array}{l}\text { Product } \\
\text { (Yield [\%])[e] }\end{array}$} \\
\hline & & Buffer, pH, conc. & & & & & \\
\hline 1 & octylamine (1c) & acetate, $\mathrm{pH} 4.5,0.5 \mathrm{M}$ & 20 & $7 \mathrm{~d}$ & 0 & - & - \\
\hline 2 & 3,4-dihydroxybenzylamine (1d) & acetate, $\mathrm{pH} 4.5,0.5 \mathrm{M}$ & 20 & $24 \mathrm{~h}$ & $>99$ & - & $-[\mathrm{f}]$ \\
\hline 3 & pyridine-3yl-methanamine (1e) & acetate, $\mathrm{pH} 4.5,0.5 \mathrm{M}$ & 20 & $7 \mathrm{~d}$ & - & - & - \\
\hline 4 & 2-methoxybenzylamine (1f) & acetate, $\mathrm{pH} 4.5,0.5 \mathrm{M}$ & 20 & $24 \mathrm{~h}$ & $>99$ & $100 / 0 / 0$ & $2 f(98)$ \\
\hline 5 & 2-methoxybenzylamine (1f) & acetate, $\mathrm{pH} 4.5,0.5 \mathrm{M}$ & 20 & $7 \mathrm{~d}$ & $>99$ & $90 / 10 / 0$ & - \\
\hline 6 & 2-methoxybenzylamine (1f) & acetate, $\mathrm{pH} 4.5,0.2 \mathrm{M}$ & 20 & $10 \mathrm{~d}$ & $>99$ & $61 / 39 / 0$ & - \\
\hline 7 & 2-methoxybenzylamine (1f) & phosphate, $\mathrm{pH} 7,0.5 \mathrm{M}$ & 5 & $7 \mathrm{~d}$ & $>99$ & $<5 / 0 / 95$ & $4 f(95)$ \\
\hline 8 & 3,4-dimethoxybenzylamine (1g) & acetate, $\mathrm{pH} 4.5,0.5 \mathrm{M}$ & 20 & $24 \mathrm{~h}$ & $>99$ & $100 / 0 / 0$ & $2 g(98)$ \\
\hline 9 & 3,4-dimethoxybenzylamine (1g) & acetate, $\mathrm{pH} 4.5,0.5 \mathrm{M}$ & 20 & $7 \mathrm{~d}$ & $>99$ & $88 / 12 / 0$ & - \\
\hline 10 & 3,4-dimethoxybenzylamine (1g) & acetate, $\mathrm{pH} 4.5,0.2 \mathrm{M}$ & 20 & $10 \mathrm{~d}$ & $>99$ & $61 / 39 / 0$ & - \\
\hline 11 & 3,4-dimethoxybenzylamine (1g) & phosphate, $\mathrm{pH} 7,0.5 \mathrm{M}$ & 5 & $5 \mathrm{~d}$ & $>99$ & $0 /<5 / 95$ & $4 g(80)$ \\
\hline 12 & para-methylbenzylamine (1h) & acetate, $\mathrm{pH} 4.5,0.5 \mathrm{M}$ & 20 & $24 \mathrm{~h}$ & $>99$ & $100 / 0 / 0$ & $2 \mathrm{~h}(95)$ \\
\hline 13 & para-methylbenzylamine (1h) & acetate, $\mathrm{pH} 4.5,0.5 \mathrm{M}$ & 20 & $7 \mathrm{~d}$ & $>99$ & $77 / 23 / 0$ & - \\
\hline 14 & para-methylbenzylamine (1h) & acetate, $\mathrm{pH} 4.5,0.2 \mathrm{M}$ & 20 & $10 \mathrm{~d}$ & $>99$ & $43 / 57 / 0$ & - \\
\hline 15 & para-methylbenzylamine (1h) & 1 equiv acetic acid & 20 & $7 \mathrm{~d}$ & $>99$ & $66 / 34 / 0$ & - \\
\hline 16 & para-methylbenzylamine (1h) & phosphate, $\mathrm{pH} 7,0.5 \mathrm{M}$ & 5 & $7 \mathrm{~d}$ & 57 & $0 / 0 / 100$ & $4 \mathrm{~h}(44)$ \\
\hline 17 & 3,5-bis(trifluoromethyl)benzylamine (1i) & acetate, $\mathrm{pH} 4.5,0.5 \mathrm{M}$ & 20 & $24 \mathrm{~h}$ & $>99$ & $57 / 0 / 43$ & - \\
\hline 18 & 3,5-bis(trifluoromethyl)benzylamine (1i) & phosphate, $\mathrm{pH}$ 7, $0.5 \mathrm{M}$ & 5 & $4 \mathrm{~d}$ & 59 & $0 / 0 / 100$ & $4 \mathrm{i}(44)$ \\
\hline 19 & ortho-chlorobenzylamine $(1 \mathrm{j})$ & acetate, $\mathrm{pH} 4.5,0.5 \mathrm{M}$ & 20 & $24 \mathrm{~h}$ & $>99$ & $100 / 0 / 0$ & $2 \mathrm{j}(99)$ \\
\hline 20 & ortho-chlorobenzylamine (1j) & acetate, $\mathrm{pH} 4.5,0.5 \mathrm{M}$ & 20 & $7 \mathrm{~d}$ & $>99$ & $50 / 50 / 0$ & - \\
\hline 21 & ortho-chlorobenzylamine (1j) & acetate, $\mathrm{pH} 4.5,0.2 \mathrm{M}$ & 20 & $10 \mathrm{~d}$ & $>99$ & $<5 / 95 / 0$ & $3 \mathrm{j}(88)$ \\
\hline 22 & ortho-chlorobenzylamine (1j) & 1 equiv. acetic acid & 20 & $7 \mathrm{~d}$ & $>99$ & $10 / 90 / 0$ & - \\
\hline 23 & ortho-chlorobenzylamine (1j) & phosphate, $\mathrm{pH} 7,0.5 \mathrm{M}$ & 5 & $5 \mathrm{~d}$ & $>99$ & $<5 / 0 / 95$ & $4 \mathrm{j}(92)$ \\
\hline 24 & para-fluorobenzylamine $(1 \mathrm{k})$ & acetate, $\mathrm{pH} 4.5,0.5 \mathrm{M}$ & 20 & $24 \mathrm{~h}$ & $>99$ & $100 / 0 / 0$ & $2 \mathrm{k}(97)$ \\
\hline 25 & para-fluorobenzylamine $(1 \mathrm{k})$ & acetate, $\mathrm{pH} 4.5,0.5 \mathrm{M}$ & 20 & $7 \mathrm{~d}$ & $>99$ & $75 / 25 / 0$ & - \\
\hline 26 & para-fluorobenzylamine $(1 \mathrm{k})$ & acetate, $\mathrm{pH} 4.5,0.2 \mathrm{M}$ & 20 & $10 \mathrm{~d}$ & $>99$ & $59 / 41 / 0$ & - \\
\hline 27 & para-fluorobenzylamine $(1 \mathrm{k})$ & phosphate, $\mathrm{pH} 7,0.5 \mathrm{M}$ & 5 & $7 \mathrm{~d}$ & 94 & $0 / 0 / 100$ & $4 \mathrm{k}(92)$ \\
\hline 28 & para-nitrobenzylamine (11) & acetate, $\mathrm{pH} 4.5,0.5 \mathrm{M}$ & 20 & $24 \mathrm{~h}$ & $>99$ & $50 / 0 / 50$ & - \\
\hline 29 & para-nitrobenzylamine (1l) & phosphate, $\mathrm{pH}$ 7, $0.5 \mathrm{M}$ & 5 & $4 \mathrm{~d}$ & 50 & $0 / 0 / 100$ & $41(36)$ \\
\hline
\end{tabular}

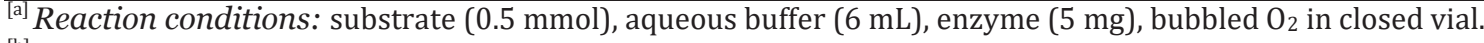

${ }^{[b]}$ Reaction time reported in days (d) or hours (h).

${ }^{[c]}$ Conversions were evaluated on crude after work-up.

${ }^{[\mathrm{d}]}$ Ratio between aldehyde, acid, and imine has been evaluated by ${ }^{1} \mathrm{H}$ NMR (see Experimental Section).

${ }^{[\mathrm{e}]}$ Yields determined on isolated products (see Experimental Section).

${ }^{[\mathrm{ff}}$ Polymerization products.
}

not react (Table 2 , entry 1 ). This result is indeed consistent with the proposed mechanism of a laccase-mediator system (LMS), which supported an ionic hydrogen abstraction route for oxidation with TEMPO[25,17] (Figure 5): in this case the acidity of the a-proton of 1c was not adequate for an efficient hydrogen abstraction. On the other hand dihydroxybenzylamine $1 \mathrm{~d}$ and pyridine-3-yl-methanamine 1e were completely converted but in a complex mixture of by-products (Table 2, entries 2 and 3). Actually, laccases are well known to oxidize phenolic compounds, which are their natural substrates in lignin, or anilines. ${ }^{[20 \mathrm{~b}]}$

Most of the benzylamines $1 \mathrm{f}-11$ were selectively converted into the corresponding aldehydes or imines in good yields depending on the selected reaction conditions. Electronic effects associated with electrondonating and electron-withdrawing substituents on the phenyl ring have little effect on the efficiency of the oxidation reaction. The amines 3,5-bis(trifluoromethyl)benzylamine (1i) and p-nitrobenzylamine (11) at $\mathrm{pH} 4.5$ gave a 1:1 mixture of the corresponding aldehydes and imines (Table 2, entries 17 and 28), whereas at $\mathrm{pH} 7$ the selectivity for the imines $4 \mathrm{i}$ and 41 was successfully obtained, albeit with lower yields (Table 2, entries 18 and 29). Product selectivity towards the carboxylic acids was obtained with buffer acetate $0.2 \mathrm{M}$ and a significant amount of acid was obtained with most benzylamines and, remarkably, 
<smiles>[R]c1ccc(C(C)N)cc1</smiles>

5a: $R=O M e$ 5b: $\mathrm{R}=\mathrm{H}$

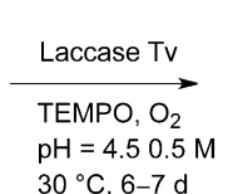

$30{ }^{\circ} \mathrm{C}, 6-7 \mathrm{~d}$<smiles>[R]c1ccc(C(C)=O)cc1</smiles>

6a: $Y=84 \%$, conv. $85 \%$

6b: $Y=97 \%$, conv. $100 \%$
Scheme 1. Oxidation of $a$-substituted benzylamines with Laccase Tv-TEMPO to give ketones.<smiles>c1ccc(CNCc2ccccc2)cc1</smiles>

7

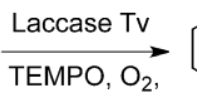
$30{ }^{\circ} \mathrm{C}, 3 \mathrm{~d}$ $\mathrm{pH}=4.50 .5 \mathrm{M}$
$\mathrm{Y}=86 \%$ conv. $99 \%$

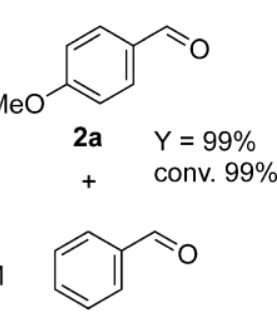

2b
Scheme 2. Oxidation of secondary dibenzylamines with Laccase Tv-TEMPO to give aldehydes.

ortho-chlorobenzylamine ( $1 \mathrm{j}$ ) in 10 days was converted in the corresponding acid $3 \mathrm{j}$ in $88 \%$ yield (Table 2 , entry 21).

We also applied the laccase/TEMPO system in the oxidation of $a$-substituted benzylamines such as 1-arylethylamines $5 \mathrm{a}, \mathrm{b}$ (Scheme 1): in both cases the corresponding acetophenones $6 \mathrm{a}, \mathrm{b}$ were obtained in good conversions and yields. The bio-oxidation was successful also with secondary benzylamines 7 and 8 , as reported in Scheme 2. Both symmetrical or unsymmetrical substituted benzylamines were readily oxidized to the corresponding aldehydes.

The easy bio-oxidation of benzylamines suggested a tentative exploration in selective oxidation of unsymmetrical secondary amines such as $N$-benzylamino esters in which the oxidation resulted in the elimination of the benzyl groups as in deprotection steps (Scheme 3). Two substrates were tested, the $N$-benzylvaline methyl ester 9 and the $N$-benzyl beta-alanine ethyl ester 10. Notwithstanding a total conversion of the starting material, products were difficulty recovered as ammonium salt (9a) or after derivatization as tert-butyloxycarbonylamino derivative (10a).

Finally, two heterocyclic amine, 2,3-dihydroisoindole 11 and tetrahydroisoquinoline 13, were tested (Scheme 4). Oxidation of dihydroisoindole 11 was not efficient, giving poor conversion and yields after 7 days of reaction, but was selective: dihydroisoindo-

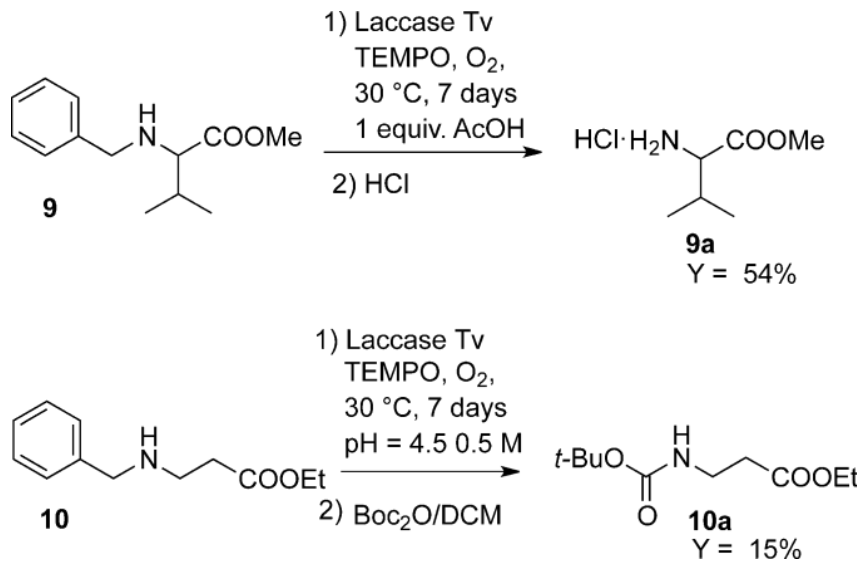

Scheme 3. Oxidation of $N$-benzylamino esters with Laccase Tv-TEMPO.
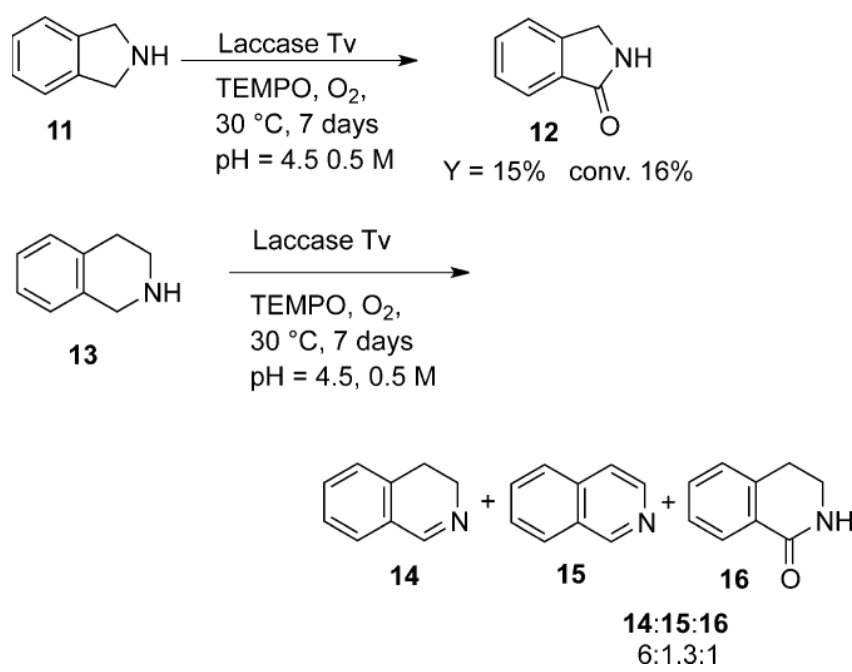

Scheme 4. Oxidation of isoindoline 11 and tetrahydroisoquinoline 13 with Laccase Tv-TEMPO.

lone 12 was the only product obtained. In the case of tetrahydroisoquinoline 13 , conversion was complete in 7 days, but in the reaction mixture, after the workup, three oxidation products were detected: among them 3,4-dihydro-isoquinoline 14 was the main component, as detected by NMR on crude.

\section{Conclusions}

Development of more benign and selective redox processes is an urgent need to get more sustainable chemical transformations, especially at the industrial level. In this context the use of commercially available enzymes such as oxidases, could represent a valuable greener alternative. We found that Laccase TvTEMPO is an effective catalytic system for the aerobic oxidation of benzylamines in aqueous medium. The product selectivity toward aldehydes or imines 
depends on the reaction conditions and specifically from $\mathrm{pH}$ of buffer solution. Under optimized reaction conditions, an efficient and practical bio-oxidation of a series of primary, secondary and cyclic amines was developed.

\section{Experimental Section}

\section{General}

Commercial reagents were used as received without additional purification. ${ }^{1} \mathrm{H}$ and ${ }^{13} \mathrm{C}$ NMR spectra were recorded with an INOVA 400 instrument with a $5 \mathrm{~mm}$ probe. TLC: Merck 60 F254 plates. HPLC-MS: Agilent Technologies HP1100 instrument, equipped with a ZORBAX-Eclipse XDBC8 Agilent Technologies column; mobile phase: $\mathrm{H}_{2} \mathrm{O}$ / $\mathrm{CH}_{3} \mathrm{CN}, 0.4 \mathrm{~mL} \mathrm{~min}^{-1}$, gradient from 30 to $80 \%$ of $\mathrm{CH}_{3} \mathrm{CN}$ in $8 \mathrm{~min}, 80 \%$ of $\mathrm{CH}_{3} \mathrm{CN}$ until 25 min, coupled with an Agilent Technologies MSD1100 single-quadrupole mass spectrometer, full scan mode from $m / z=50$ to 2600 , scan time $0.1 \mathrm{~s}$ in positive ion mode, ESI spray voltage $4500 \mathrm{~V}$, nitrogen gas $35 \mathrm{psi}$, drying gas flow $11.5 \mathrm{~mL} \mathrm{~min}^{-1}$, fragmentor voltage $20 \mathrm{~V}$. Starting amines $1 \mathrm{a}-1 \mathrm{l}, 5 \mathrm{a}, \mathrm{b}, 7,11,13$, laccase from Trametes versicolor and TEMPO were purchased from Sigma-Aldrich (Sigma 51639, $10 \mathrm{U} / \mathrm{mg}$ ), benzylamines 8, 9 and 10 were prepared by alkylation with benzyl bromide (see the Supporting Information for details). All obtained products were known and their spectroscopic data (see the Supporting Information for details) were consistent with those reported in the literature and in NMR databases (Reaxys and AIST SDBS).

\section{General Procedure to Obtain Aldehydes}

To a stirred solution of the amine $(0.5 \mathrm{mmol})$ in the appropriate solvent, (acetate buffer $\mathrm{pH} 4.50 .5 \mathrm{M}$ or 1 equiv. of acetic acid in $\left.\mathrm{H}_{2} \mathrm{O}\right)(6 \mathrm{~mL})$ in a $10-\mathrm{mL}$ vial with a screw cap, TEMPO $(0.1 \mathrm{mmol})$ and the enzyme $(5 \mathrm{mg}, 50 \mathrm{U})$ were added. $\mathrm{O}_{2}$ was bubbled for 30 seconds and the vial was closed. The solution was stirred on an orbital shaker at $150 \mathrm{rpm}$ and kept at 30 8C in thermostat. After completion (TLC monitoring), the aqueous solution was extracted with EtOAc ( $3 \times 5 \mathrm{~mL})$. The aqueous phase was then adjusted to pH 2 by slow addition of aqueous $\mathrm{HCl}(1 \mathrm{M})$ and then extracted with EtOAc $(3 \times 5 \mathrm{~mL})$. The collected organic phases were dried over $\mathrm{Na}_{2} \mathrm{SO}_{4}$, filtered, concentrated under vacuum and analysed by ${ }^{1} \mathrm{H}$ NMR and ${ }^{13} \mathrm{C}$ NMR (see the Supporting Information).

\section{General Procedure to Obtain Imines}

To a stirred solution of the amine $(0.5 \mathrm{mmol})$ in buffer phosphate $\mathrm{pH} 7.5,0.5 \mathrm{M}(6 \mathrm{~mL})$ in a $10-\mathrm{mL}$ vial with a screw cap TEMPO $(0.025 \mathrm{mmol})$ and the enzyme $(5 \mathrm{mg})$ were added and then $\mathrm{O}_{2}$ was bubbled for 30 seconds. The solution was stirred on an orbital shaker at $150 \mathrm{rpm}$ and kept at 30 8C in a thermostat. When the reaction was complete or after 7 days, the aqueous solution was extracted with $\mathrm{CH}_{2} \mathrm{Cl}_{2}(3 \mathrm{x}$ $5 \mathrm{~mL}$ ) and EtOAc ( $3 \times 5 \mathrm{~mL})$. The aqueous phase was then adjusted to $\mathrm{pH} 9$ by slow addition of aqueous $\mathrm{NaOH}(1 \mathrm{M})$ and then extracted with $\mathrm{CH}_{2} \mathrm{Cl}_{2}(3 \times 5 \mathrm{~mL})$. The collected or- ganic phases were dried over $\mathrm{Na}_{2} \mathrm{SO}_{4}$, filtered, concentrated under vacuum, and analysed by ${ }^{1} \mathrm{H}$ NMR and ${ }^{13} \mathrm{C}$ NMR (see the Supporting Information).

\section{Acknowledgements}

We are grateful to the University of Bologna for financial support and to CINMPIS (Consorzio Interuniversitario Nazionale Metodologie e Processi Innovativi di Sintesi) for a grant to F.F.; Dr. M. Pori, Mr. A Ballardini and Mrs. Giulia Martelli are also acknowledged for technical assistance and useful discussions.

\section{References}

[1] M. G. Turcotte, K. S. Hayes, Amines, Lower Aliphatic Amines, in: Kirk-Othmer Encyclopedia of Chemical Technology, John Wiley and Sons, 2001, DOI: 10.1002/ 0471238961.1215230520211803.a01.pub2.

[2] a) M. Largeron, Eur. J. Org. Chem. 2013, 5225-5235, and references cited therein; b) S. E. Allen, R. R. Walvoord, R. Padilla-Salinas, M. C. Kozlowski, Chem. Rev. 2013, 113, 6234-6458, and references cited therein.

[3] a) M. T. Schuemperli, C. Hammond, I. Hermans, ACS Catal. 2012,2,1108-1117, and references cited therein; b) J. S. M. Samec, A. H. Ell, J.-E. Backvall, Chem. Eur. J. 2005, 11, 2327-2334.

[4] G. Chu, C. Li, Org. Biomol. Chem. 2010, 8, 4716-4719.

[5] a) Z. Hu, F. M. Kerton, Org. Biomol. Chem. 2012, 1O, 1618-1624; b) T. Sonobe, K. Oisaki, M. Kanai, Chem. Sci. 2012, 3, 3249-3255.

[6] a) For a recent review on aerobic oxidation catalysis with stable radicals see: Q. Cao, L. M. Dornan, L. Rogan, N. L. Hughes, M. J. Muldoon, Chem. Commun. 2014, 50, 4524-4543 ; b) R. A. Sheldon, I. W. C. E. Arends, Adv. Synth. Catal. 2004, 346, 1051-1071.

[7] a) X. Qiu, C. Len, R. Luque, Y. Li, ChemSusChem 2014, 7, 1684-1688 ; b) A. Dhakshinamoorthy, M. Alvaro, H. Garcia, ChemCatChem 2010, 2, 1438-1443.

[8] a) E. R. Klobukowski, R. J. Angelici, L. K. Woo, Catal. Lett. 2012, 142, 161-167; b) B. Zhu, R. J. Angelici, Chem. Commun. 2007, 2157-2159.

[9] a) T. B. Nguyen, L. Ermolenko, A. Al-Mourabit, Green Chem. 2013, 15, 2713-2717; b) L. Liu, S. Zhang, X. Fu, C.-H. Yan, Chem. Commun. 2011, 47,10148-10150.

[10] a) X.-J. Yang, B. Chen, X.-B. Li, L.-Q. Zheng, L.-Z. Wu, C.-H. Tung, Chem. Commun. 2014, 5o, 6664-6667; b) N. Li, X. Lang, W. Ma, H. Ji, C. Chen, J. Zhao, Chem. Commun. 2013, 49, 5034-5036.

[11] a) D. Romano, R. Villa, F. Molinari, ChemCatChem 2012, 4, 739-749; b) D. Monti, G. Ottolina, G. Carrea, S. Riva, Chem. Rev. 2011, 111, 4111-4140 ; c) M. Hall, A. S. Bommarius, Chem. Rev. 2011, 111, 4088-4110.

[12] a) F. Hollmann, I. W. C. E. Arends, K. Buehler, A. Schallmey, B. Biihlerb, Green Chem. 2011, 13, 226-265; b) R. D. Schmid, V. B. Urlacher, (Eds.), Modern Biooxidation. Enzymes, Reactions and Applications. WileyVCH, Weinheim, 2007. 
[13] a) For a very recent review on copper-enzymes, see: E. I. Solomon, D. E. Heppner, E. M. Johnston, J. W. Ginsbach, J. Cirera, M. Qayyum, M. T. KieberEmmons, C. H. Kjaergaard, R. G. Hadt, L. Tia, Chem. Rev. 2014, 114, 3659-3853; b) N. J. Turner, Chem. Rev. 2011, 111, 4073-4087; c) M. Mure, S. A. Mills, J. P. Klinman, Biochemistry 2002, 41, 9269-9278.

[14] a) A. E. Wendlandt, S. S. Stahl, J. Am. Chem. Soc. 2014, 136, 506-512; b) M. Largeron, M.-B. Fleury, Science 2013, 339, 43-44 ; c) M. Largeron, M.-B. Fleury, Angew. Chem. 2012, 124, 5505-5508; Angew. Chem. Int. Ed. 2012, 51, 5409-5412; d) A. E. Wendlandt, S. S. Stahl, Org. Lett. 2012, 14, 2850-2853.

[15] a) For a review on laccases see: P.Giardina, V.Faraco, C. Pezzella, A. Piscitelli, S. Vanhulle, G. Sannia, Cell. Mol. Life Sci. 2010, 67, 369-385, and references cited therein; b) S. Witayakran, A. J. Ragauskas, Adv. Synth. Catal. 2009, 351, 1187-1209.

[16] a) J.-R. Jeon, Y.-S. Chang, Trends Biotechnol. 2013, 31 335-341; b) J. Polak, A. Jarosz-Wilkolazka, Process Biochem. 2012, 47, 1295-1307; c) A. I. CaÇas, S. Camarero, Biotechnol. Adv. 2010, 28,694-705.

[17] a) M. Mogharabi, M. A. Faramarzi, Adv. Synth. Catal. 2014, 356, 897-927, and references cited therein; b) C. Galli, P.Gentili, J. Phys. Org. Chem. 2004, 17, 973-977.

[18] a) S. Riva, Trends Biotechnol. 2006, 24, 219-226; b) I. W. C. E. Arends, Y-X. Li, R. Ausan, R. A. Sheldon, Tetrahedron 2006, 62,6659-6665.

[19] P. Galletti, M. Pori, F. Funiciello, R. Soldati, A. Ballardini, D. Giacomini, ChemSusChem 2014, 7, 2684-2689.
[20] a) A. Diaz-Rodriguez, L. Martinez-Montero, I. Lavandera, V. Gotor, V. Gotor-Fernandez, Adv. Synth. Catal. 2014, 356, 2321-2329; b) A. C. Sousa, M. C. Oliveira, L. O. Martins, M. P. Robalo, Green Chem. 2014, 16, 4127-4136; c) A. C. Sousa, L. O. Martins, M. P. Robalo, Adv. Synth. Catal. 2013, 355, 2908-2917; d) A. Wells, M. Teria, T. Eve, Biochem. Soc. Trans. 2006, 34, 304308; e) A. Kollmann, F.-D. Boyer, P.-H. Ducrot, L. Kerhoas, C. Jolivalt, I. Touton, J. Einhorn, C. Mougin, Appl. Microbiol. Biotechnol. 2005, 68, 251-258.

[21] For the dependence of Laccase Tv activity on $\mathrm{pH}$, see for instance: a) S. K. S. Patel, V. C. Kalia, J.-H. Choi, J.R. Haw, I.-W. Kim, J. K. Lee, J. Microbiol. Biotechnol. 2014, 24, 639-647; b) I. Eichlerovffl, J. Šnajdr, P. Baldrian, Chemosphere 2012, 88, 1154-1160.

[22] J. C. Qiu, P.P.Pradhan, N. B. Blanck, J. M. Bobbitt, W. F. Bailey, Org. Lett. 2012, 14, 350-353, and references cited therein.

[23] a) See, for instance, in the supporting material of: $\mathrm{H}$. Yuan, W.-J. Yoo, H. Miyamura, S. Kobayashi, J. Am. Chem. Soc. 2012, 134, 13970-13973 ; b) J. F. Dellaria, W. H. Moser, M. R. Radmer, G. W. Griesgraber, PCT Int. Appl. WO 2007028129 A1, 2007.

[24] H. Huang, J. Huang, Y.-M. Liu, H.-Y. He, Y. Cao, K.N. Fan, Green Chem. 2012, 14, 930-934.

[25] a) F. d'Acunzo, C. Galli, P.Gentili, F. Sergi, New J. Chem. 2006, 30, 583-591; b) F. d'Acunzo, P. Baiocco, M. Fabbrini, C. Galli, P. Gentili, Eur. J. Org. Chem. 2002, 4195-4201. 